Article

\title{
Study of crystallization process of SAPO-11 molecular sieve
}

\author{
LI Bing a , TIAN Peng a, QI Yue a, ZHANG Lin a , XU Shutao a, SU Xiong a,b, FAN Dong a,b, LIU Zhongmin ${ }^{\text {a,* }}$ \\ a Dalian National Laboratory for Clean Energy, National Engineering Laboratory for Methanol-to-Olefins, Dalian Institute of Chemical Physics, \\ Chinese Academy of Sciences, Dalian 116023, Liaoning, China \\ ${ }^{\mathrm{b}}$ University of Chinese Academy of Sciences, Beijing 100049, China
}

\section{A R T I C L E I N F}

Article history:

Received 21 November 2012

Accepted 30 December 2012

Published 20 March 2013

Keywords:

SAPO-11 molecular sieve

Characterization

Crystallization process

Silicon distribution

\begin{abstract}
A B S T R A C T
The crystallization process of SAPO-11 was studied using a combination of X-ray diffraction, scanning electron microscopy, X-ray fluorescence, nuclear magnetic resonance, and X-ray photoelectron spectroscopy. In the initial stage of crystallization, SAPO-11 was formed along with an unknown crystalline material composed of $\mathrm{Si}-\mathrm{P}-\mathrm{Al}$. As crystallization evolved, the crystalline material dissolved. The SAPO-11 formation rate increased greatly, which is characteristic of fast crystallization. After $2.33 \mathrm{~h}$, the relative crystallinity of SAPO-11 reached $\sim 100 \%$ and remained at a high level until crystallization was complete. Si was incorporated into the SAPO-11 framework from the initial stage of crystallization. The Si content of the solid samples increased with crystallization time. Most of the $\mathrm{Si}$ atoms existed as Si islands in the SAPO-11 framework, resulting in the presence of multiple coordination environments, i.e., $\mathrm{Si}(n \mathrm{Al},(4-n) \mathrm{Si}), n=0-4$. X-ray photoelectron spectroscopy analysis revealed Si enrichment on the external surfaces of the SAPO-11 crystals. Based on the experimental results, the distribution of $\mathrm{Si}$ in the crystals is not uniform, showing an increasing trend from the core to the surface.
\end{abstract}

(C) 2013, Dalian Institute of Chemical Physics, Chinese Academy of Sciences. Published by Elsevier B.V. All rights reserved.

\section{Introduction}

The first synthesis of silicoaluminophosphate molecular sieves (SAPO- $n$ ) was reported by the Union Carbide Corporation in the 1980s [1]. SAPO-11 is one of the most important members of the SAPO family. It consists of elliptical, one-dimensional, 10-membered-ring channels with a pore opening of $0.40 \mathrm{~nm} \times 0.65 \mathrm{~nm}$ [2]. SAPO-11 molecular sieve has outstanding thermal and hydrothermal stabilities, and has played an important role in petrochemical processes, such as isomerization, catalytic cracking, hydrocracking, and isodewaxing $[3,4]$. It is worth pointing out that SAPO-11 exhibits excellent catalytic reactivity in the isodewaxing of lubricant oils, which is already used in industry [5].

SAPO-11 molecular sieve is mainly synthesized using hydrothermal methods, and detailed studies of SAPO-11 synthesis have been carried out by many researchers. Wang et al. [6] investigated the effects of the Si source, Si content, amount of template, and crystallization conditions (temperature, time and $\mathrm{pH}$ ) on SAPO-11 synthesis. They found that the Si source is one of the main factors affecting the synthesis and structure of SAP0-11. Liu et al. [7] used di- $n$-propylamine (DPA), diisopropylamine, or a mixture of these as templates for synthesizing SAPO-11. They found that the impurities that appeared in the synthesis using a single template can be effectively avoided by using a dual-template method. Liu et al. [8] studied the effect of the synthesis conditions on the distribution of $\mathrm{Si}$ in the framework of SAPO-11 molecular sieve. Prolonging the crystallization time, raising the temperature, lowing the $\mathrm{Si} / \mathrm{Al}$ ratio, and controlling the $\mathrm{pH}$ of the initial gels promote uniform distribution of Si in the framework. They obtained SAPO-11 molecular sieve with highly dispersed Si. Zhang et al. [9] investigated the

* Corresponding author. Tel/Fax: +86-411-84379335; E-mail: liuzm@dicp.ac.cn

DOI: 10.1016/S1872-2067(12)60542-7 | http://www.sciencedirect.com/science/journal/18722067 | Chin. J. Catal.,Vol. 34, No. 3, March 2013 
synthesis and characterization of SAPO-11 molecular sieve in the presence of hydrofluoric acid (HF). Compared with the synthesis in the absence of HF, adding HF increases the crystallization rate and crystallinity of SAPO-11 molecular sieve. Microwave synthesis [10], solvothermal synthesis [11], and dry-gel methods $[12,13]$ have also been reported for the synthesis of SAP0-11 molecular sieve.

Huang et al. [12] used solid-state nuclear magnetic resonance (NMR) spectroscopy and other methods to study the crystallization process of AlPO-11 synthesized by dry-gel conversion. They found that the initial amorphous material is first converted to a semicrystalline intermediate with 10-membered-ring channels. As the crystallization proceeds, the intermediate is transformed into AlPO-11. They also used ${ }^{17} \mathrm{O}$ NMR spectroscopy to investigate the effect of water on the AlPO-11 crystallization process during dry-gel conversion. Direct evidence of the involvement of water in molecular sieve crystallization was obtained [14]. Zhang et al. [15] studied the influence of water content on the hydrothermal crystallization of AlP0-11, using ultraviolet (UV), Raman, X-ray diffraction (XRD), and NMR characterization methods. They proposed possible intermediate fragments in the crystallization process of AlPO-11, based on a combination of their experimental results and theoretical computations [16]. So far, there have been few detailed studies of the crystallization process of SAPO-11. The crystallization process of SAPO-11 might be different from that of AlPO-11 because of the presence of Si. However, it is very important to determine the status and distribution of $\mathrm{Si}$ in SAPO-11 with increasing crystallization time because the incorporation of Si into the molecular sieve framework generates acidic centers with catalytic properties. Studies of the crystallization process of SAPO-11 can improve understanding of the crystallization mechanism. They will also be helpful in effectively controlling SAPO-11 synthesis.

In this paper, SAPO-11 molecular sieve was synthesized using a hydrothermal method in a 2-L autoclave with a sampling pipeline. The samples obtained at different times were characterized by XRD, X-ray fluorescence spectroscopy (XRF), scanning electron microscopy (SEM), magic-angle spinning (MAS) NMR, and X-ray photoelectron spectroscopy (XPS) methods. Some new insights into the crystallization process of SAPO-11 molecular sieves were obtained.

\section{Experimental}

\subsection{Preparation of SAPO-11 molecular sieve}

In all syntheses, pseudoboehmite $\left(\mathrm{Al}_{2} \mathrm{O}_{3}, 67 \mathrm{wt} \%\right)$, silica sol $\left(\mathrm{SiO}_{2}, 27.5 \mathrm{wt} \%\right)$, and phosphoric acid (85 wt\%) were used as sources of $\mathrm{Al}, \mathrm{Si}$, and $\mathrm{P}$, respectively. The template was DPA (chemically pure). The initial gel was prepared by mixing all the raw materials in a molar composition of 1.1 DPA:0.4 $\mathrm{SiO}_{2}: 0.86$ $\mathrm{Al}_{2} \mathrm{O}_{3}: 1 \quad \mathrm{P}_{2} \mathrm{O}_{5}: 55 \mathrm{H}_{2} \mathrm{O}$. The mixture was transferred into a $2-\mathrm{L}$ stainless-steel autoclave, and the autoclave was sealed. The temperature was gradually raised to $200{ }^{\circ} \mathrm{C}$, with continuous stirring, and kept stable for crystallization. The crystallization time was recorded from the start of heating. Liquid samples were removed at different times. At sampling times of 0.75 and $1.22 \mathrm{~h}$, the corresponding temperatures were 100 and $150{ }^{\circ} \mathrm{C}$, respectively. After $1.83 \mathrm{~h}$, the temperature reached $200{ }^{\circ} \mathrm{C}$ and was then kept constant. The liquid samples were cooled to room temperature. The liquid phase was separated from the solids by centrifugation. The solid materials were washed with water and then dried at $120^{\circ} \mathrm{C}$.

\subsection{Preparation of other SAPO molecular sieves}

Triethylamine (TEA) was used as a template for the synthesis of SAPO-5. The initial gel composition was 1.2 TEA:0.4 $\mathrm{SiO}_{2}: 1 \mathrm{Al}_{2} \mathrm{O}_{3}: 1 \mathrm{P}_{2} \mathrm{O}_{5}: 60 \mathrm{H}_{2} \mathrm{O}$. SAPO-5 was crystallized at $200{ }^{\circ} \mathrm{C}$ for $17 \mathrm{~h}$.

In a similar procedure, SAPO-34 was synthesized using TEA as the template. The initial gel composition was 3.5 TEA:0.3 $\mathrm{SiO}_{2}: 1 \mathrm{Al}_{2} \mathrm{O}_{3}: 1 \mathrm{P}_{2} \mathrm{O}_{5}: 55 \mathrm{H}_{2} \mathrm{O}$. SAPO-34 was crystallized at $200{ }^{\circ} \mathrm{C}$ for $48 \mathrm{~h}$. The sample was labeled SAPO-34-TEA.

SAPO-35 was synthesized using hexamethyleneimine (HMI) as the template. The initial gel composition was $1.33 \mathrm{HMI}: 0.5$ $\mathrm{SiO}_{2}: 1 \mathrm{Al}_{2} \mathrm{O}_{3}: 0.96 \mathrm{P}_{2} \mathrm{O}_{5}: 55 \mathrm{H}_{2} \mathrm{O}$. SAPO-35 was crystallized at 200 ${ }^{\circ} \mathrm{C}$ for $24 \mathrm{~h}$.

\subsection{Characterization}

Powder XRD patterns were recorded on a PANalytical X'Pert PRO X-ray diffractometer, using $\mathrm{Cu} K_{\alpha}(\lambda=0.15418 \mathrm{~nm})$ radiation at $40 \mathrm{kV}$ and $40 \mathrm{~mA}$. Element analysis was performed using a Philips Magix 2424X XRF spectrometer. The morphologies of samples were examined by SEM, using a KYKY-AMRAY1000B instrument (CAS Scientific Instrument Company). Solid-state NMR spectra were recorded on a Bruker AvanceIII 600 spectrometer. The resonance frequencies of ${ }^{29} \mathrm{Si},{ }^{27} \mathrm{Al}$, and ${ }^{31} \mathrm{P}$ were 119.2, 156.4, and 242.9 MHz, respectively. ${ }^{29} \mathrm{Si}$ MAS NMR spectra were acquired using a 7-mm probe with proton decoupling; $2.5 \mu \mathrm{s}$, corresponding to a $\pi / 4$ pulse length, was applied, with a 10-s delay and a rotor spinning rate of $5 \mathrm{kHz}$. 4,4-Dimethyl-4-silapentane-1-sulfonic acid was used as the chemical shift reference. ${ }^{27} \mathrm{Al}$ MAS NMR spectra were recorded using a 4-mm probe with a $\pi / 8$ pulse length of $0.75 \mu \mathrm{s}$, a 2-s delay, and a rotor spinning rate of $13 \mathrm{kHz} . \mathrm{NH}_{4} \mathrm{Al}\left(\mathrm{SO}_{4}\right)_{2} \cdot 12 \mathrm{H}_{2} \mathrm{O}$ was used as a secondary chemical shift reference $\left(\delta_{\mathrm{Al}}=-0.4\right)$. 31P MAS NMR spectra were measured using a 4-mm probe with high-power proton decoupling at a spinning speed of $10 \mathrm{kHz}$. A $\pi / 4$ pulse strength of $2.25 \mu$ s was used with a delay of $4 \mathrm{~s}$. The chemical shift of ${ }^{31} \mathrm{P}$ was referenced to $85 \%$ phosphoric acid aqueous solution. XPS measurements were performed using a Thermo ESCALAB 250Xi spectrometer with $\mathrm{Al} K_{\alpha}$ radiation as the excitation source. The surface charge of the sample was calibrated by referencing to the $\mathrm{Al} 2 p$ peak of $\mathrm{Al}_{2} \mathrm{O}_{3}$ at $74.7 \mathrm{eV}$.

\section{Results and discussion}

\section{1. $X R D$}

Figure 1 shows the XRD patterns of as-synthesized samples with different crystallization time. In the initial crystallization 


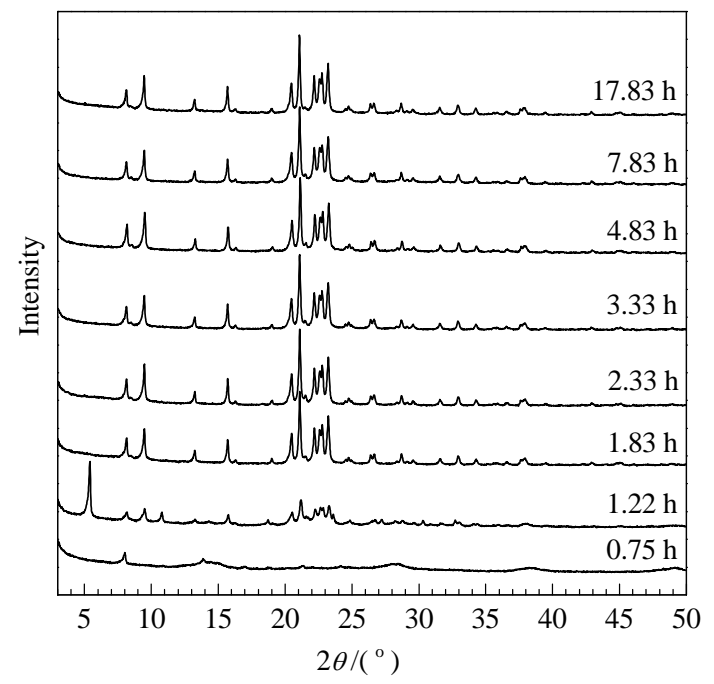

Fig. 1. XRD patterns of as-synthesized samples with different crystallization time.

stage $(0.75 \mathrm{~h})$, the solid sample was mainly composed of amorphous boehmite because of the short crystallization time and low temperature [17]. However, a weak peak at $8^{\circ}$ can be found in the XRD pattern, indicating the appearance of a small amount of crystalline material in the system. After $1.22 \mathrm{~h}$, the typical diffraction peaks of SAPO-11 molecular sieve, at 8.1 $9.5^{\circ}, 13.2^{\circ}, 15.7^{\circ}$, and $21^{\circ}$, were detected, implying formation of the SAPO-11 crystalline phase. There were two obvious peaks, at $5.4^{\circ}$ and $10.8^{\circ}$, which were not diffraction peaks of SAPO- 11 . Based on the peak positions, these might be from a layered crystalline phase. These two peaks disappeared after the temperature reached $200{ }^{\circ} \mathrm{C}(t=1.83 \mathrm{~h})$. Pure SAPO-11 molecular sieve was then obtained.

Based on an intensity summary of the six strongest peaks in the XRD patterns of SAPO-11, the relative crystallinity of the sample at different crystallization times was calculated (the

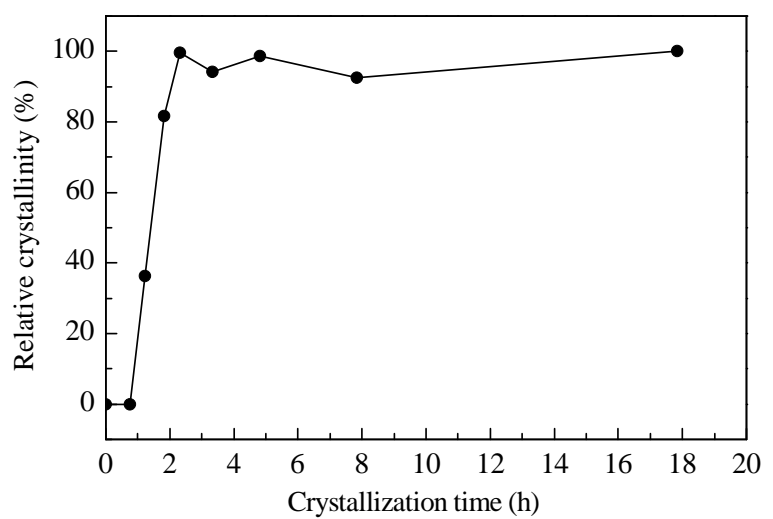

Fig. 2. Crystallization curve of SAPO-11.

crystallinity of the sample at $17.83 \mathrm{~h}$ was defined as $100 \%$ ). The crystallization curve for SAPO-11 is shown in Fig. 2. Before $2.33 \mathrm{~h}$, the relative crystallinity increased sharply with increasing crystallization time. At $1.83 \mathrm{~h}$, the relative crystallinity of the sample reached $81 \%$. This is close to $100 \%$, the value at a crystallization time of $2.33 \mathrm{~h}$. The relative crystallinity later fluctuated within a certain range ( $>90 \%)$. These results indicated fast crystallization of SAPO-11 molecular sieve.

\subsection{SEM}

Figure 3 shows the SEM images of as-synthesized samples with different crystallization times. At $0.75 \mathrm{~h}$, only amorphous material appeared in the solid sample. For a crystallization time of $1.22 \mathrm{~h}$, some spherical aggregates of SAPO-11 were observed. In addition, there was a small amount of strip crystals. As the crystallization time increased, the amount of amorphous materials gradually decreased. At $1.83 \mathrm{~h}$, the strip crystals totally disappeared, and the amount of spherical aggregation increased significantly. The morphology of the solid sample then remained almost unchanged with time.

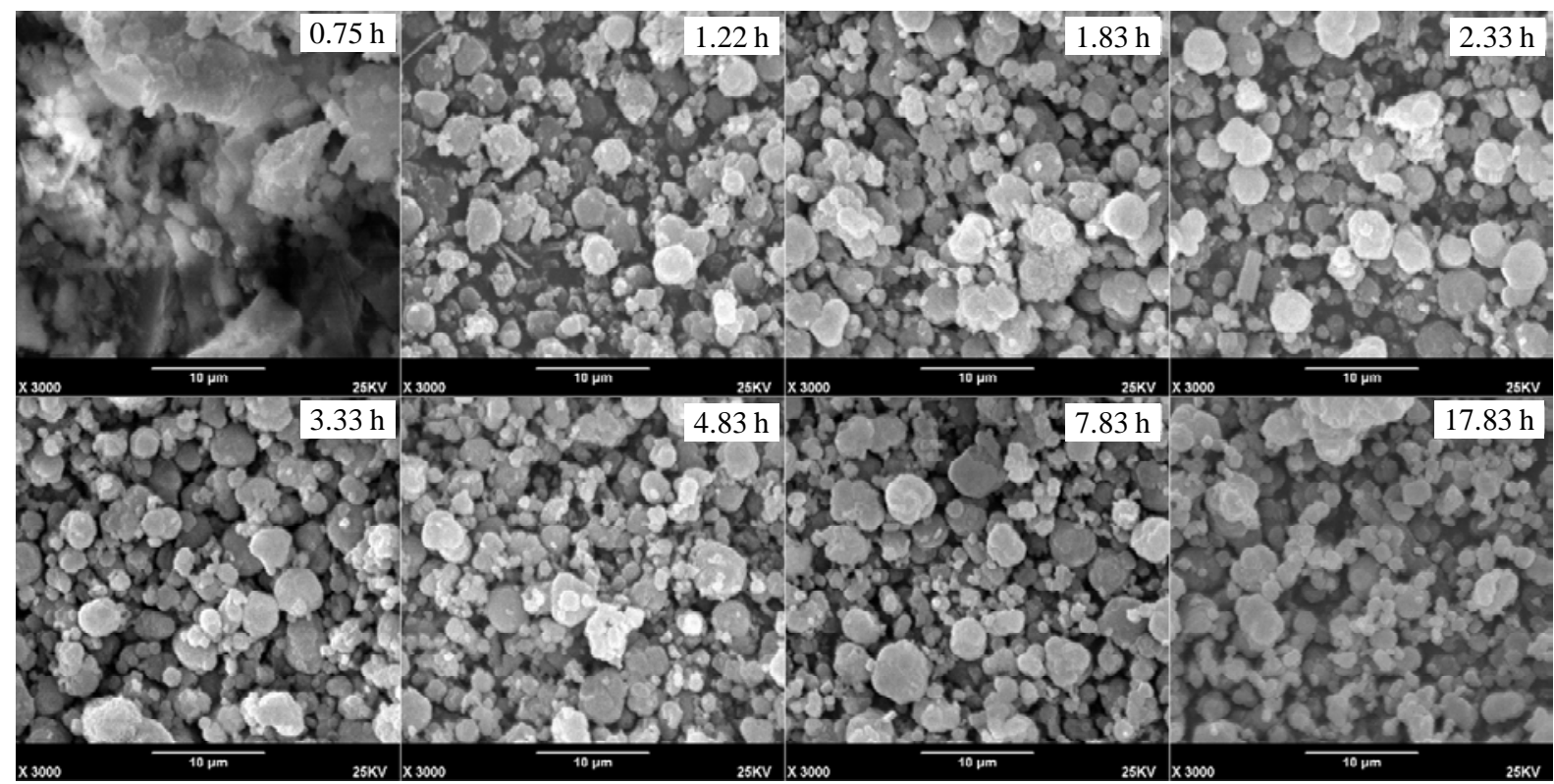

Fig. 3. SEM images of as-synthesized samples with different crystallization time. 


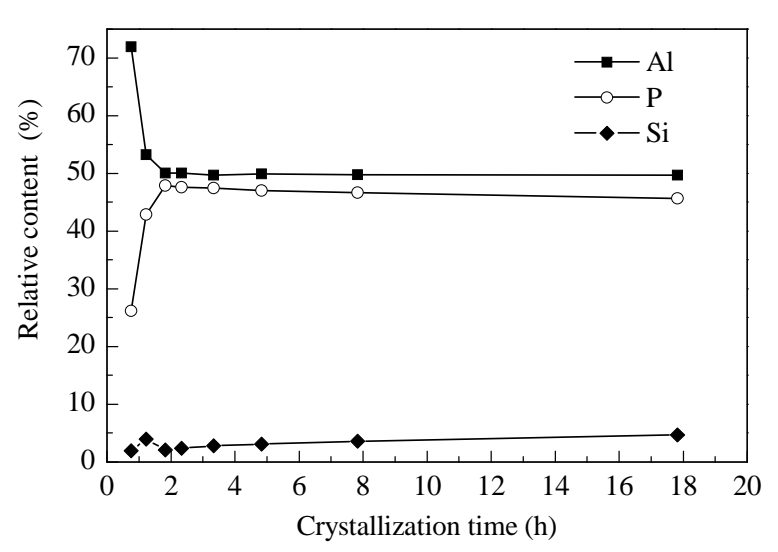

Fig. 4. Chemical compositions of as-synthesized samples with different crystallization time.

\section{3. $X R F$}

The chemical compositions of the as-synthesized samples were obtained using XRF. Figure 4 shows the changes in the relative molar contents of $\mathrm{P}, \mathrm{Al}$, and $\mathrm{Si}$ in the solid samples at different crystallization time. In the initial stage of crystallization (before $1.83 \mathrm{~h}$ ), the $\mathrm{P}$ content of the solid samples increased significantly (from $26.14 \%$ at $0.75 \mathrm{~h}$ to $47.89 \%$ at 1.83 $\mathrm{h}$ ), but that of $\mathrm{Al}$ decreased rapidly (from $71.9 \%$ at $0.75 \mathrm{~h}$ to $50.05 \%$ at $1.83 \mathrm{~h}$ ). This indicates that $\mathrm{Al}$ species from the raw materials continued to dissolve into the liquid phase with time, and the amorphous materials observed by SEM in the early crystallization period should be mainly from unreacted alumina. As the crystallization time increased, the Al content of the solid samples was stable at 50\%, the P content showed a weak downward trend, and the content of Si increased correspondingly. The sum of the numbers of moles of $\mathrm{Si}$ and $\mathrm{P}$ remained around $50 \%$, close to that of $\mathrm{Al}$. It is worth noting that the $\mathrm{Si}$ content of the sample at $1.22 \mathrm{~h}$ showed a maximum value. In addition, comparing the sample at $1.83 \mathrm{~h}$ with the final product shows that the change in the relative molar content of $\mathrm{Si}$ was larger than those of $\mathrm{P}$ and $\mathrm{Al}$. The content of $\mathrm{Si}$ in the sample at $1.83 \mathrm{~h}$ was $2.06 \%$. This increased 1.26 -fold to $4.66 \%$ at $17.83 \mathrm{~h}$.

\subsection{Crystallization solution $\mathrm{pH}$}

The $\mathrm{pH}$ of the crystallization solution is closely related to the status of all the raw materials under the synthesis conditions. Before $2.33 \mathrm{~h}$, the $\mathrm{pH}$ of the crystallization solution increased significantly with increasing crystallization time (shown in Fig. 5). After that, there were only small changes in the $\mathrm{pH}$. Considering the above results, we concluded that the rapid increase in the $\mathrm{pH}$ of the solution during the initial crystallization period, up to $2.33 \mathrm{~h}$, was caused by consumption of phosphoric acid and aluminum oxide in the reaction. Correspondingly, a large amount of molecular sieves were synthesized. In addition, as the $\mathrm{P}$ content of the solution decreased, the organic amine that combined with phosphoric acid in the initial stage was gradually released, which also resulted in an increase in the $\mathrm{pH}$. After $2.33 \mathrm{~h}$, the $\mathrm{pH}$ of the crystallization solution remained almost unchanged.

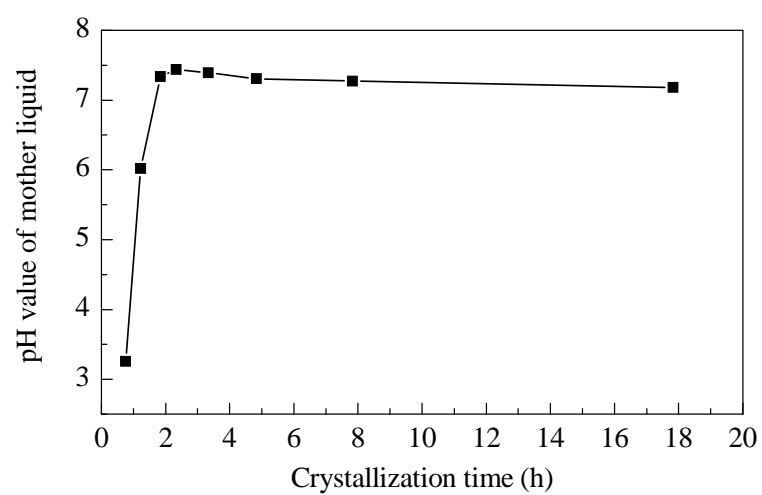

Fig. 5. pH values of crystallization solutions at different crystallization time.

\subsection{Solid-state MAS NMR}

${ }^{31} \mathrm{P}$ and ${ }^{27} \mathrm{Al}$ MAS NMR spectra of the as-synthesized samples at different crystallization time are shown in Fig. 6 respectively. Only one broad peak, at $\delta=-16$, is observed in the ${ }^{31 P}$ MAS NMR spectrum of the sample at $0.75 \mathrm{~h}$. This peak can be as-

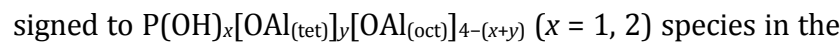
amorphous aluminophosphate phase [18]. Correspondingly, there are two resonance peaks in the ${ }^{27} \mathrm{Al}$ MAS NMR spectrum of the sample, which are related to five-coordinated $(\delta=8)$ and six-coordinated $(\delta=-12)$ Al species in the amorphous $\mathrm{Al}$
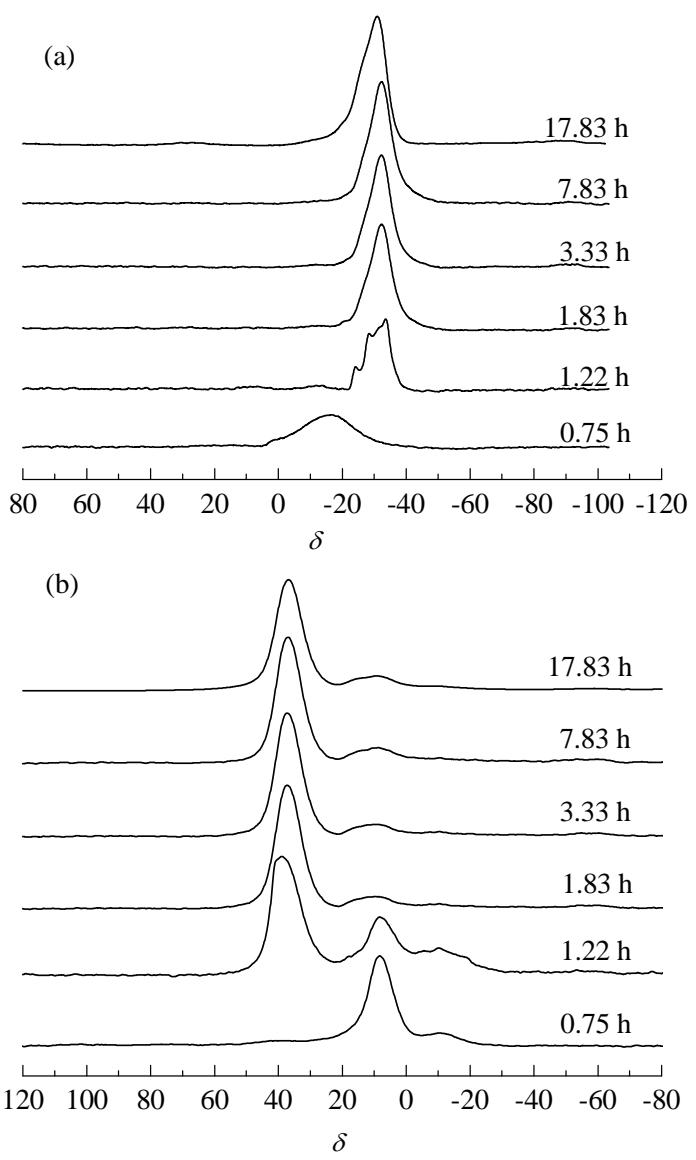

Fig. 6. ${ }^{31} \mathrm{P}$ MAS NMR (a) and ${ }^{27} \mathrm{Al}$ MAS NMR (b) spectra of as-synthesized samples. 
source and amorphous aluminophosphate, respectively $[11,19,20]$. After $1.22 \mathrm{~h}$, the broad peak in the ${ }^{31} \mathrm{P}$ MAS NMR spectrum almost disappeared, indicating that there was a smaller amount of amorphous aluminophosphate left in the sample. At the same time, several relatively sharp peaks at $\delta=$ $-24,-28.4$, and -33.6 appeared in the spectrum, arising from highly crystalline four-coordinated $\mathrm{P}$ species in the aluminophosphate $[12,18]$. This demonstrates that the $\mathrm{P}$ species in the solid samples were highly condensed and the $\mathrm{P}$ atoms had complex coordination environments. In addition, obvious changes can be observed in the ${ }^{27} \mathrm{Al}$ MAS NMR spectrum. A strong asymmetric resonance appeared at $\delta=38.8$. The intensity of the peak at $\delta=8$ became weak. Generally, the chemical shifts of tetrahedral Al species in microporous aluminophosphate materials are in the range $\delta=35-48$ [21]. The new resonance at $\delta=38.8$ in the sample at $1.22 \mathrm{~h}$ is therefore assigned to four-coordinated $\mathrm{Al}$ species. The weakening of the peak at 8 ppm indicates that the content of amorphous Al source in the solid samples was decreasing, which is in agreement with the $\mathrm{XRF}$ results. It is worth pointing out that the intensity of the peak at $\delta=-12$, from six-coordinated Al species, did not decrease with dissolution of amorphous aluminophosphate and the Al source, from which it can be deduced that newly formed $\mathrm{Al}$ species contribute to the same chemical shift at $\delta=-12$. The ${ }^{31} \mathrm{P}$ and ${ }^{27} \mathrm{Al}$ MAS NMR spectra of the samples were almost unchanged after crystallization for $1.83 \mathrm{~h}$ or longer. The resonance at $\delta=-32$ (including the shoulder at $\delta=-26$ ) in the ${ }^{31} \mathrm{P}$ MAS NMR spectrum is attributed to tetrahedrally coordinated $\mathrm{P}$ species in the SAPO-11 framework [12,20]. The peaks at $\delta=37$ and 8 in the ${ }^{27} \mathrm{Al}$ MAS NMR spectrum are from four-coordinated and five-coordinated $\mathrm{Al}$ species in the framework of the molecular sieves $[12,17]$. These results suggest that the crystallization of SAPO-11 was almost complete, and are consistent with the XDR, SEM, and XRF results.

Comparing the spectra of the samples in the late period of crystallization suggests that the peak at $\delta=-12$ in the ${ }^{27} \mathrm{Al}$ MAS NMR spectrum of the sample at $1.22 \mathrm{~h}$, from octahedral $\mathrm{Al}$ species, should be related to the crystalline intermediate phase. As well as tetrahedral Al species $(\delta=37)$ in SAPO-11, the asymmetric resonance at $\delta=38.8$ in the ${ }^{27} \mathrm{Al}$ MAS NMR spectrum is also attributed to $\mathrm{Al}$ species in the intermediate phase. Correspondingly, several peaks in the ${ }^{31} \mathrm{P}$ MAS NMR spectrum are also correlated with the intermediate phase. These results demonstrate that the coordination environments of the $\mathrm{Al}$ and $P$ species in the intermediate phase are very complex.

Figure 7(a) presents the ${ }^{29} \mathrm{Si}$ MAS NMR spectra of solid samples at different crystallization times. The spectra of all the samples show a similar broad resonance. Comparing the spectra of the samples at different times, we found that the relative intensity of the peak at $\delta=-109$ in the spectrum of the sample at $1.22 \mathrm{~h}$ was higher than those of the other samples. Reports in the literature [2,22-24] show that $\mathrm{Si}$ atoms can exist as $\mathrm{Si}(n \mathrm{Al}$, $(4-n) \mathrm{Si})(n=0-4)$ in the framework of SAPO molecular sieves. As the number of $\mathrm{Al}$ atoms around $\mathrm{Si}$ decreases, the $\mathrm{Si}$ resonance shifts to a higher field (-90 to -110$)$. The peak broadening in the ${ }^{29} \mathrm{Si}$ MAS NMR spectra of the sample at $1.83 \mathrm{~h}$ and other highly crystalline samples indicates that there are several

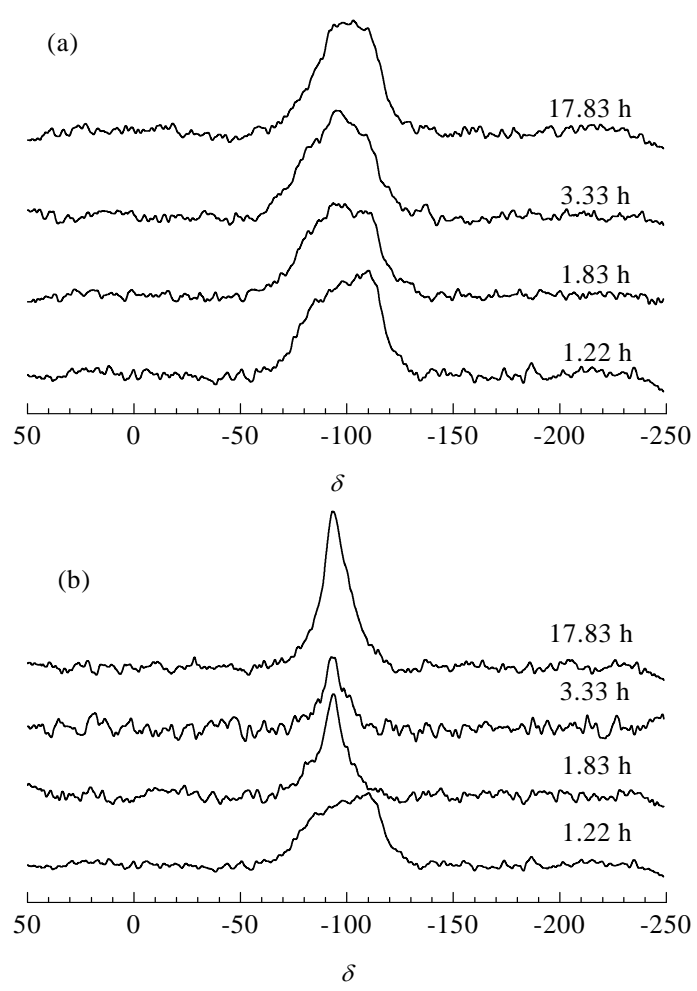

Fig. 7. ${ }^{29} \mathrm{Si}$ MAS NMR (a) and ${ }^{1} \mathrm{H}-{ }^{29} \mathrm{Si}$ CP MAS NMR (b) spectra of as-synthesized samples.

types of Si species in the frameworks of the solid samples. Since the sample has two crystal phases in the initial crystallization period (at $1.22 \mathrm{~h}$ ), as well as a small amount of amorphous materials, it is difficult to assign all the peaks in the ${ }^{29} \mathrm{Si}$ MAS NMR spectrum. Therefore, ${ }^{1} \mathrm{H}-{ }^{29} \mathrm{Si}$ cross-polarization (CP) MAS NMR spectra were obtained. The spectra are shown in Fig. 7(b). It is obvious that almost no changes can be observed in the spectrum of the sample at $1.22 \mathrm{~h}$ after cross polarization. However, a sharp peak at $\delta=-93.7[\mathrm{Si}(3 \mathrm{Al})]$ appeared in the ${ }^{29} \mathrm{Si} \mathrm{CP}$ MAS NMR spectra of other solid samples, instead of the broad peak seen in the ${ }^{29} \mathrm{Si}$ MAS NMR spectra. The difference between the peak intensity of the sample at $1.22 \mathrm{~h}$ and those of the other solid samples in the range -75 to -100 could be correlated with the existence of crystalline intermediates. The assignment of the peak at $\delta=-110$ is still difficult. This peak might arise from the intermediate phase, or it could be related to undissolved raw materials in the liquid phase. Comparing the ${ }^{29} \mathrm{Si}$ MAS NMR and ${ }^{29} \mathrm{Si}$ CP MAS NMR spectra of the solid samples in the later period of crystallization, we infer that the Si atoms exist as Si islands in the molecular sieve framework at this stage. Based on the SM2 (Si substituting P) and SM3 (Si substituting P-Al) mechanisms for incorporation of Si into the SAPO framework, five- and eight-Si islands can be formed in the framework. The structure with five-Si islands contains four $\mathrm{Si}(3 \mathrm{Al}, 1 \mathrm{Si})$ and one $\mathrm{Si}(4 \mathrm{Si})$. The structure with eight-Si islands contains four $\mathrm{Si}(3 \mathrm{Al}$, 1Si), two $\mathrm{Si}(2 \mathrm{Al}, 2 \mathrm{Si})$, and two $\mathrm{Si}(4 \mathrm{Si})[25,26]$. The structures with five-Si islands and eight-Si islands both result in the existence of many $\mathrm{Si}(3 \mathrm{Al})$ species. This is in agreement with the ${ }^{29} \mathrm{Si}$ MAS NMR spectra. 


\subsection{Analysis of crystallization process}

Based on the above results, we consider the crystallization process of SAPO-11 molecular sieves to be as follows.

Significant changes in the initial gel started to occur when heating started. When the crystallization temperature reached $100{ }^{\circ} \mathrm{C}$, most of the $\mathrm{P}$ and $\mathrm{Si}$ sources had dissolved into the liquid phase. However, the Al source remained in the solid phase as pseudoboehmite. In addition, some amorphous aluminophosphate appeared in the solid samples. When the temperature rose to $150{ }^{\circ} \mathrm{C}$, large amounts of the $\mathrm{Al}$ source and amorphous aluminophosphate dissolved into the liquid phase. At the same time, SAPO-11 crystals and an unknown crystalline phase started to appear. The Al content of the solid samples decreased significantly, and the $\mathrm{P}$ and $\mathrm{Si}$ contents of the solid samples clearly increased. Moreover, the Si content reached a local maximum point. The $\mathrm{pH}$ of the solution increased from 3.26 at $100{ }^{\circ} \mathrm{C}$ to 6.02 at $150{ }^{\circ} \mathrm{C}$. Theoretically, in the initial crystallization period, with the increase in the $\mathrm{pH}$, it is easy for amorphous silicon oxide to dissolve into the liquid phase. The increase in the Si content of the solid sample should be caused by formation of the intermediate phase, suggesting the existence of Al-P-Si in intermediates. Based on the NMR results, we can deduce that the coordination environments of these atoms in the intermediate phase are more complex than those in SAPO-11. When the crystallization temperature reached $200{ }^{\circ} \mathrm{C}$, amorphous aluminum oxide and the intermediate crystal dissolved completely. A large amount of SAPO-11 started to crystallize, and the relative crystallinity of the sample was $81 \%$. In addition, the solution $\mathrm{pH}$ rose to 7.34. The molar content of $\mathrm{Si}$ in the sample was only $2.06 \%$. It existed as Si islands in the framework of the SAPO-11 molecular sieve. On extension of the crystallization time to $17.83 \mathrm{~h}$, the coordination environments of $\mathrm{Al}, \mathrm{Si}$, and $\mathrm{P}$ in the solid sample remained unchanged. The relative molar content of $\mathrm{Al}$ was around $50 \%$. The content of $\mathrm{P}$ decreased slightly, and that of $\mathrm{Si}$ increased to $4.66 \%$. This means that the amount of Si incorporated into the framework increased greatly in the later stages of crystallization.

\subsection{Si distribution in SAPO molecular sieve crystals}

Based on analysis of the crystallization process, we infer that the distribution of Si in SAPO-11 molecular sieve might be inhomogeneous, and increase from the inside to the surface. This results in a large amount of Si on the external surface of SAPO. To confirm our deduction, XPS was performed on the sample at $17.83 \mathrm{~h}$. The results are listed in Table 1 . The results show that the $\mathrm{Si} / \mathrm{Al}$ ratio on the external surface is around 0.48 , which is much higher than the value of 0.09 in the bulk phase, obtained using XRF. This result is in agreement with our previous analysis. This phenomenon could be closely related to changes in the $\mathrm{pH}$ of the system. Since the isoelectric point of silicon oxide is at around $\mathrm{pH} 2$, the solution in the initial crystallization stage is acidic, which is not conducive to depolymerization of silicon oxide. The involvement of $\mathrm{Si}$ is therefore restricted to formation of the framework. As the crystallization process proceeds and various products are formed, the solution
Table 1

Bulk and surface compositions of SAPO molecular sieves.

\begin{tabular}{lcc}
\hline Sample & \multicolumn{1}{c}{ Bulk } & \multicolumn{1}{c}{ Surface } \\
\hline SAPO-11 & $\mathrm{Si}_{0.045} \mathrm{Al}_{0.498} \mathrm{P}_{0.458}$ & $\mathrm{Si}_{0.224} \mathrm{Al}_{0.462} \mathrm{P}_{0.314}$ \\
SAPO-5 & $\mathrm{Si}_{0.073} \mathrm{Al}_{0.488} \mathrm{P}_{0.439}$ & $\mathrm{Si}_{0.155} \mathrm{Al}_{0.420} \mathrm{P}_{0.424}$ \\
SAPO-34-TEA & $\mathrm{Si}_{0.080} \mathrm{Al}_{0.486} \mathrm{P}_{0.434}$ & $\mathrm{Si}_{0.206} \mathrm{Al}_{0.453} \mathrm{P}_{0.341}$ \\
SAPO-34-DEA & $\mathrm{Si}_{0.164} \mathrm{Al}_{0.478} \mathrm{P}_{0.358}$ & $\mathrm{Si}_{0.231} \mathrm{Al}_{0.440} \mathrm{P}_{0.329}$ \\
SAPO-35 & $\mathrm{Si}_{0.122} \mathrm{Al}_{0.488} \mathrm{P}_{0.390}$ & $\mathrm{Si}_{0.187} \mathrm{Al}_{0.478} \mathrm{P}_{0.335}$ \\
\hline
\end{tabular}

*Data from Ref. [15]. SAPO-34-DEA was synthesized with diethylamine as template.

pH rises gradually. Increasing amounts of silicon oxide are depolymerized, resulting in an increase in the number of active Si species in the liquid phase. The amount of Si atoms incorporated into the framework therefore increases significantly, resulting in a large amount of $\mathrm{Si}$ on the external surfaces of the molecular sieves.

According to the literature, it is common for the $\mathrm{pH}$ of a synthetic gel to increase as the crystallization of SAPO molecular sieves progresses. We therefore deduced that Si enrichment of the external surface may occur for other SAPO molecular sieves (that is, the Si content of the crystal increases from the core to the shell). So, SAPO-5, SAPO-34, and SAPO-35 molecular sieves were hydrothermally synthesized and characterized by XPS. The results are presented in Table 1 . The Si contents on the surfaces of these samples are higher than those in the bulk phase, in agreement with the above speculation. In addition, there are differences among the surface Si contents of the samples. This might be related to the $\mathrm{pH}$ of each synthetic solution and the framework structure of the molecular sieves. The phenomenon of Si enrichment on the surface of SAPO molecular sieves has also been reported by other research groups $[27,28]$. It should be a common characteristic of the crystallization of SAPO molecular sieves.

\section{Conclusions}

The hydrothermal crystallization process of SAPO-11 molecular sieve was investigated using several characterization methods. In the early stage of crystallization, the $\mathrm{Si}, \mathrm{P}$, and $\mathrm{Al}$ sources, as well as the amorphous aluminophosphate gel, dissolved into the liquid phase. SAPO-11 was formed along with a crystalline material composed of $\mathrm{Si}-\mathrm{P}-\mathrm{Al}$. As crystallization continued, the unknown crystalline material dissolved, and SAP0-11 crystallized with fast crystallization characteristics. After heating the gel for $2.33 \mathrm{~h}$, the relative crystallinity of the molecular sieves was close to $100 \%$. This fluctuated within a small range until crystallization was complete. The crystallization process of SAPO-11 followed a solution-mediated transport mechanism, although a solid hydrogel transformation mechanism may also occur in the initial stage of crystallization. $\mathrm{Si}$ atoms were incorporated directly into the SAPO-11 framework in the initial stage of crystallization and existed as Si islands. Considering that the content of silicon oxide in the molecular sieves increased gradually with increasing crystallization time, and based on the XPS results, we deduced that the distribution of Si in the SAPO-11 crystal was not uniform. The content of Si increased from the core to the surface of the crys- 


\section{Graphical Abstract}

Chin. J. Catal., 2013, 34: 593-603 doi: 10.1016/S1872-2067(12)60542-7

\section{Study of crystallization process of SAPO-11 molecular sieve}

LI Bing, TIAN Peng, QI Yue, ZHANG Lin, XU Shutao, SU Xiong, FAN Dong, LIU Zhongmin* Dalian Institute of Chemical Physics, Chinese Academy of Sciences; Graduate University of Chinese Academy of Sciences

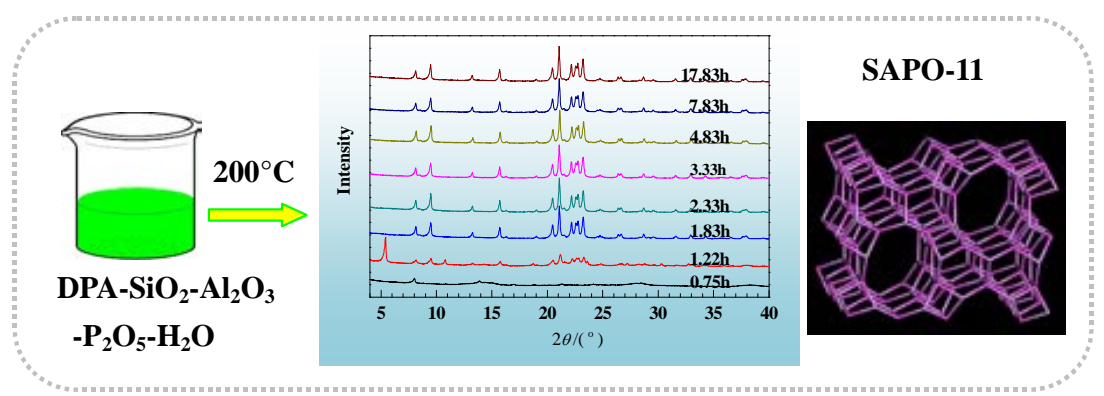

The formation of SAPO-11 exhibited fast crystallization characteristics. The Si content of SAPO-11 increased with time, which led to a non-uniform distribution of $\mathrm{Si}$ in the crystals.

tal. In addition, we compared the XPS results of other SAPO molecular sieves. We found enriched Si species on the external surfaces of all the SAPO molecular sieves. We therefore conclude that it is common for the distribution of Si in SAPO molecular sieves synthesized by hydrothermal methods to be non-uniform.

\section{References}

[1] Lok B M, Messina C A, Patton R L, Gajek R T, Cannan T R, Flanigen E M. US Patent 4440871.1984

[2] Zhang Sh Zh, Chen Sh L, Dong P, Yuan G M, Xu K Q. Appl Catal A, 2007, 332: 46

[3] Luo H J, Wu H J, Wu H Y, Zhang Y Y, Wang Y J. Ind Catal (罗洪君, 吴 红姣, 吴红玉, 张莹莹, 汪颖军. 工业催化), 2011, 19(1): 16

[4] Wang Y J, Li X H, Liu Ch Sh, Jin L L. Ind Catal (汪颖军, 李小辉, 刘 成双, 靳丽丽. 工业催化), 2010, 18(3): 1

[5] Tian Zh J, Liang D B, Lin L W. Chin J Catal (田志坚, 梁东白, 林励 吾. 催化学报), 2009, 30: 705

[6] Wang Zh M, Yan Z F. J Fuel Chem Technol (汪哲明, 阎子峰. 燃料化 学学报), 2003, 31: 360

[7] Liu Y M, Zhang F M, Shu X T. Acta Petrol Sin (Petrol Proc Sect) (刘 月明, 张凤美, 舒兴田. 石油学报(石油加工)), 2002, 18(6): 26

[8] Liu P, Ren J, Sun Y H. Acta Petrol Sin (Petrol Proc Sect) (刘平, 任杰, 孙予罕. 石油学报(石油加工)), 2008, 24(4): 388

[9] Zhang Sh Zh, Chen Sh L, Dong P, Jing X J, Jiang K. Chin J Catal (张胜 振, 陈胜利, 董鹏, 井秀娟, 姜凯. 催化学报), 2006, 27: 868

[10] Gharibeh M, Tompsett G A, Conner W C. Top Catal, 2008, 49: 157

[11] Sinha A K, Seelan S. Appl Catal A, 2004, 270: 245
[12] Chen B H, Huang Y N.J Phys Chem C, 2007, 111: 15236

[13] Song Ch M, Feng Y, Ma L L. Microporous Mesoporous Mater, 2012, 147: 205

[14] Chen B H, Huang Y N.J Am Chem Soc, 2006, 128: 6437

[15] Zhang B, Xu J, Fan F T, Guo Q, Tong X Q, Yan W F, Yu J H, Deng F, Li C, Xu R R. Microporous Mesoporous Maters, 2012, 147: 212

[16] Cheng T, Xu J, Li X, Li Y, Zhang B, Yan W F, Yu J H, Sun H, Deng F, Xu R R. Microporous Mesoporous Mater, 2012, 152: 190

[17] Liu G Y, Tian P, Zhang Y, Li J Zh, Xu L, Meng Sh H, Liu Zh M. Microporous Mesoporous Mater, 2008, 114: 416

[18] Huang Y N, Richer R, Kirby C W.J Phys Chem B, 2003, 107: 1326

[19] Zhang L, Bates J, Chen D H, Nie H Y, Huang Y N. J Phys Chem C, 2011, 115: 22309

[20] Lutz W, Kurzhals R, Sauerbeck S, Toufar H, Buhl J Chr, Gesing T, Altenburg W, Jäger Chr. Microporous Mesoporous Mater, 2010, 132: 31

[21] Yan Zh M, Chen B H, Huang Y N. Solid State Nucl Magn Reson, 2009, 35: 49

[22] Borade R B, Clearfield A. J Mol Catal, 1994, 88: 249

[23] Wang Sh F, Wang Y J, Gao Y, Zhao X Q. Chin J Catal (王淑芳, 王延 吉, 高扬, 赵新强. 催化学报), 2010, 31: 637

[24] Blasco T, Chica A, Corma A, Murphy W J, Agúndez-Rodriguez J, Pérez-Pariente J. J Catal, 2006, 242: 153

[25] Barthomeuf D. J Phys Chem, 1993, 97:10092

[26] Shen W L, Li X, Wei Y X, Tian P, Deng F, Han X W, Bao X H. Microporous Mesoporous Mater, 2012, 158: 19

[27] Kikhtyanin O V, Toktarev A V, Ayupov A B, Echevsky G V. Appl Catal A, 2010, 378: 96

[28] Akolekar D B, Bhargava S K, Gorman J, Paterson P. Colloids Surf A, 1999, 146: 375

\section{SAPO-11分子篮晶化过程研究}

李 冰 ${ }^{\mathrm{a}}$, 田 鹏 ${ }^{\mathrm{a}}$, 齐 越 ${ }^{\mathrm{a}}$, 张 琳 ${ }^{\mathrm{a}}$, 徐舒涛 ${ }^{\mathrm{a}}$, 苏 雄 ${ }^{\mathrm{a}, \mathrm{b}}$, 㚞 栋, ${ }^{\mathrm{a}, \mathrm{b}}$, 刘中民,

$\mathrm{a}$ 中国科学院大连化学物理研究所洁净能源国家实验室(筹), 甲醇制烯烃国家工程实验室, 辽宁大连116023

b 中国科学院大学, 北京100049

摘要: 采用X射线衍射、X射线苂光光谱、扫描电镜和固体核磁等方法研究了SAPO-11分子笁的水热晶化过程. 结果表明,晶化初 期, SAPO-11和一种具有磷硅铝组成的未知晶相同时生成; 随着晶化的进行, 中间相溶解, SAPO-11的生成速率大大增加, 呈现快速 
晶化的特征; 至2.33 h后, SAPO-11的结晶度接近 $100 \%$, 并保持至晶化结束. 硅从晶化初期即参与了 SAPO-11的形成, 它在晶体中的 含量随晶化时间的延长而逐渐增加. 硅原子主要以硅岛的形式分布于SAPO-11分子篮骨架中, 从而导致多种硅配位环境的存在. 分析显示, SAPO-11分子篮呈现外表面富硅的特点, 结合晶化过程的分析可推测, 硅在SAPO-11分子篮晶体中的分布不均匀, 其含 量从内向外递增.

关键词: SAPO-11分子篮; 表征; 晶化过程; 硅分布

收稿日期: 2012-11-21. 接受日期: 2012-12-30. 出版日期: 2013-03-20.

*通讯联系人. 电话/传真: (0411)84379335; 电子信箱: liuzm@dicp.ac.cn

本文的英文电子版由Elsevier出版社在ScienceDirect上出版(http://www.sciencedirect.com/science/journal/18722067).

\section{1. 前言}

磷酸硅铝分子笁(SAPO- $n$ )由美国联碳公司于 $20 世$ 纪 80 年代首次合成并报道 ${ }^{[1]}$. SAPO-11是其中重要一员, 它具有椭圆形的一维十元环孔道, 孔尺寸为 0.40 $\mathrm{nm} \times 0.65 \mathrm{~nm}^{[2]} . \mathrm{SAPO}-11$ 分子篮具有优异的热和水热稳 定性, 可广泛应用于异构化、催化裂化、加氢裂化和异 构脱蜡等石油化工过程 ${ }^{[3,4]}$; 尤其在润滑油馏分的异构脱 蜡过程中, 它显示出了优异的催化性能, 目前已经得到工 业应用 ${ }^{[5]}$.

SAPO-11分子篮主要采用水热法合成, 人们从不同 的角度对 SAPO-11的合成过程进行了研究. 汪哲明等 ${ }^{[6]}$ 研究了硅源、硅含量、模板剂用量以及晶化条件(晶化 温度、时间以及 $\mathrm{pH}$ 值)在SAPO-11分子篎合成中的作用， 发现硅源是决定SAPO-11分子篮合成及结构的关键因 素之一. 刘月明等 ${ }^{[7]}$ 以二正丙胺(DPA)、二异丙胺(DIPA) 或其混合物为模板剂合成SAPO-11时发现, 采用双胺法 合成能有效地避免单胺法合成中易出现杂晶的问题. 刘 平等 ${ }^{[8]}$ 研究了合成条件对SAPO-11分子篮骨架 $\mathrm{Si}$ 分布的 影响, 发现延长晶化时间、升高晶化温度、降低硅/铝比 或控制初始溶胶 $\mathrm{pH}$ 值都可以促进骨架 $\mathrm{Si}$ 的均匀分布, 得 到具有较高 $\mathrm{Si}$ 分散度的SAPO-11分子篮. 张胜振等 ${ }^{[9]}$ 研 究了含HF体系中SAPO-11分子篮的合成及表征, 发现 SAPO-11分子篮晶化速度比常规无HF体系的更快, 结晶 度提高. 此外, 微波加热 ${ }^{[10]}$, 溶剂热合成 ${ }^{[11]}$ 和气相晶化 法 ${ }^{[12,13]}$ 等也见诸报道.

晶化机理研究方面, Huang课题组 ${ }^{[12]}$ 利用固体核磁 等(NMR)方法研究了干胶转化法合成AIPO-11分子篮的 晶化过程, 发现初始无定形材料首先转化成一种具有类 10 元环孔道的半结晶中间相, 随着晶化时间的延长, 中间 相逐渐转变成AlPO-11. 他们还利用 ${ }^{17} \mathrm{O} N \mathrm{NMR}$ 研究了 AlPO-11干胶晶化过程中水的作用, 获得了水参与晶化 的直接证据 ${ }^{[14]}$. Yan课题组 ${ }^{[15]}$ 利用UV Raman、X射线衍 射(XRD)、NMR等多种表征手段, 研究了水量变化对 AlPO-11水热晶化过程的影响; 同时他们结合理论计算,
讨论了AlPO-11晶化过程中可能存在的中间体片段, 并 在此基础上对 AlPO-11的整个晶化途径进行了推测 ${ }^{[16]}$. 目前, 关于SAPO-11晶化过程的详细研究较少. 一方面由 于硅的存在有可能使得SAPO-11的晶化过程与AlPO-11 存在差别; 另一方面, 研究硅随晶化时间在SAPO-11晶体 中的存在状态和分布的变化也具有重要意义,因为正是 由于硅的进入使得分子篮产生具有催化性能的酸中心. 对SAPO-11晶化过程的研究不仅可以深入理解晶化机 理,也有助于增加对SAPO-11合成过程的调控能力.

本文采用具有连续取样功能的 $2 \mathrm{~L}$ 釜进行了 SAPO-11分子篮的水热合成, 并通过XRD、X射线荧光光 谱(XRF)、扫描电镜(SEM)、MAS NMR和X射线光电子 能谱(XPS)等手段对不同时间晶化的样品进行分析, 以 深入认识SAPO-11的晶化过程.

\section{2. 实验部分}

\subsection{SAPO-11分子篮的制备}

实验过程中所使用的铝源、硅源和磷源分别采用拟 薄水铝石粉 $\left(\mathrm{Al}_{2} \mathrm{O}_{3} 67 \%\right.$, 质量分数, 下同)、硅溶胶 $\left(\mathrm{SiO}_{2}\right.$, $27.5 \%)$ 和磷酸 $\left(\mathrm{H}_{3} \mathrm{PO}_{4}, 85 \%\right)$; 模板剂为二正丙胺(DPA, 化 学纯 ). 按照 $n(\mathrm{DPA}): n\left(\mathrm{SiO}_{2}\right): n\left(\mathrm{Al}_{2} \mathrm{O}_{3}\right): n\left(\mathrm{P}_{2} \mathrm{O}_{5}\right): n\left(\mathrm{H}_{2} \mathrm{O}\right)=$ 1.1:0.4:0.86:1.0:55的比例将各原料混合均匀制成初始凝 胶, 然后将其移入 $2 \mathrm{~L}$ 不锈钢合成釜中并密封, 在搅拌下 逐渐升温至 $200{ }^{\circ} \mathrm{C}$ 并保持恒温晶化. 升温即开始计时, 在 不同时间点从釜中在线取样. 取样时间分别为 0.75 和 $1.22 \mathrm{~h}$ 时, 对应的温度分别为 100 和 $150{ }^{\circ} \mathrm{C}$; 而取样时间为 $1.83 \mathrm{~h}$ 及其后的温度均为 $200^{\circ} \mathrm{C}$. 取出的样品冷却至室 温, 离心分离得到母液和固体样品, 固体样品经充分水洗 后于 $120^{\circ} \mathrm{C}$ 烘干.

\section{2. 其它SAPO分子篮的制备}

SAPO-5 的合成以三乙胺 (TEA) 为模板剂, 按照 $n$ (TEA): $n\left(\mathrm{SiO}_{2}\right): n\left(\mathrm{Al}_{2} \mathrm{O}_{3}\right): n\left(\mathrm{P}_{2} \mathrm{O}_{5}\right): n\left(\mathrm{H}_{2} \mathrm{O}\right)=1.2: 0.4: 1.0: 1.0$ : 60 的比例配制初始凝胶, 晶化条件为 $200{ }^{\circ} \mathrm{C}, 17 \mathrm{~h}$.

SAPO-34 的合成以三乙胺为模板剂, 按照 $n$ (TEA): $n\left(\mathrm{SiO}_{2}\right): n\left(\mathrm{Al}_{2} \mathrm{O}_{3}\right): n\left(\mathrm{P}_{2} \mathrm{O}_{5}\right): n\left(\mathrm{H}_{2} \mathrm{O}\right)=3.5: 0.3: 1.0: 1.0$ : 
55 的比例配制初始凝胶, 晶化条件为 $200{ }^{\circ} \mathrm{C}, 48 \mathrm{~h}$. 产品记 为SAPO-34-TEA.

SAPO-35的合成以六亚甲基亚胺(HMI)为模板剂, 按照 $n(\mathrm{HMI}): n\left(\mathrm{SiO}_{2}\right): n\left(\mathrm{Al}_{2} \mathrm{O}_{3}\right): n\left(\mathrm{P}_{2} \mathrm{O}_{5}\right): n\left(\mathrm{H}_{2} \mathrm{O}\right)=1.33: 0.5$ : 1.0:0.96:55的比例配制初始凝胶, 晶化条件为 $200{ }^{\circ} \mathrm{C}, 24$ h.

\section{3. 样品的表征}

XRD采用PANalytical X'Pert PRO X射线衍射仪, $\mathrm{Cu}$ 靶, $K_{a}$ 辐射源 $(\lambda=0.15418 \mathrm{~nm})$, 电压 $40 \mathrm{kV}$, 电流 $40 \mathrm{~mA}$. 采 用Philips公司的Magix 2424X型射线苂光光谱仪对样品 进行元素分析. 样品形貌分析采用中国科学院科学仪器 厂KYKY-AMRAY-1000B型SEM.

固态NMR表征在Bruker AvanceIII 600型核磁共振 波谱仪上进行. ${ }^{29}$ Si MAS NMR谱图的测定在 $7 \mathrm{~mm}$ 探头, ${ }^{29} \mathrm{Si}$ 的共振频率 $119.2 \mathrm{MHz}$ 下进行的, 采用质子去偶, $\pi / 4$ 脉冲宽度为 $2.5 \mu \mathrm{s}$, 弛豫延迟为 $10 \mathrm{~s}$, 转速为 $5 \mathrm{kHz}$, 其化学 位移参考采用三甲基硅丙磺酸钠(DSS)为外标. ${ }^{27} \mathrm{Al}$ MAS NMR 谱图的测定在 $4 \mathrm{~mm}$ 探头, ${ }^{27} \mathrm{Al}$ 的共振频率 156.4 MHz下进行, 采用 $\pi / 8$ 脉冲宽度为 $0.75 \mu \mathrm{s}$ 和 $2 \mathrm{~s}$ 的弛 豫延迟, 转速为 $13 \mathrm{kHz}$, 其化学位移以 $\mathrm{NH}_{4} \mathrm{Al}\left(\mathrm{SO}_{4}\right)_{2}$. $12 \mathrm{H}_{2} \mathrm{O}$ 为二次参考外标 $\left(\delta_{\mathrm{Al}}=-0.4\right) .{ }^{31} \mathrm{P}$ MAS NMR 谱图 的测定在 $4 \mathrm{~mm}$ 探头, ${ }^{31} \mathrm{P}$ 的共振频率 $242.9 \mathrm{MHz}$ 下进行, 采用高功率质子去偶, $\pi / 4$ 脉冲宽度为 $2.25 \mu \mathrm{s}$, 弛豫延迟 为 $4 \mathrm{~s}$, 转速为 $13 \mathrm{kHz}$, 化学位移以 $85 \% \mathrm{H}_{3} \mathrm{PO}_{4}$ 溶液为参考 外标. XPS采用Thermo ESCALAB 250Xi型X射线光电子 能谱仪进行测定 (以单色化 $\mathrm{Al} K_{\alpha}$ 为激发源), 以样品表面 $\mathrm{Al}_{2} \mathrm{O}_{3}$ 的 $(\mathrm{Al} 2 p=74.7 \mathrm{eV}$ 为内标来校正样品表面的荷电.

\section{3. 结果与讨论}

\subsection{XRD结果}

图1是不同晶化时间制得样品的XRD谱. 可以看到, 在晶化的初始阶段 $(0.75 \mathrm{~h})$, 由于晶化时间短且温度较低, 固体样品主要是未晶化的无定形一水软铝石胶 ${ }^{[17]}$. 同 时, 在 $2 \theta=8^{\circ}$ 附近存在一个很弱的衍射峰, 说明晶化体系 中已经出现了少量具有结晶性质的物质. $1.22 \mathrm{~h}$ 的样品 在 $2 \theta=8.1^{\circ}, 9.5^{\circ}, 13.2^{\circ}, 15.7^{\circ}$ 和 $21^{\circ}$ 等处出现明显的 SAPO-11分子篮特征衍射峰, 表明SAPO-11晶相开始生 成; 但在 $2 \theta=5.4^{\circ}$ 和 $10.8^{\circ}$ 出现两个明显的非SAPO-11特 征衍射峰. 从衍射峰的位置判断, 这有可能为一种层状 结晶相. 当晶化时间进一步延长, 晶化温度达到 $200{ }^{\circ} \mathrm{C}$ 后 (1.83 h及其后样品), 非特征衍射峰消失, 所得固体样品 为纯相SAPO-11分子篎.
以SAPO-11的XRD谱图中 6 个最强峰的峰面积之和 为基准,计算不同晶化时间样品的相对结晶度(17.83 h 样 品结晶度计为 $100 \%)$, 得到 SAPO-11分子篮的晶化曲线, 结果见图2. 可以看出, 在晶化 $2.33 \mathrm{~h}$ 前, 样品的相对结 晶度随着晶化时间的延长而快速增加, 至 $1.83 \mathrm{~h}$ 时达到 $81 \%, 2.33 \mathrm{~h}$ 时接近 $100 \%$; 此后随着晶化时间延长, 相对 结晶度在一定范围内波动, 但都大于 $90 \%$. 这说明 SAPO-11具有快速晶化的特征.

\subsection{SEM结果}

图3是不同晶化时间制得SAPO-11分子笁的SEM照 片. 由图可见, $0.75 \mathrm{~h}$ 时样品中只有无定形物质; 而 $1.22 \mathrm{~h}$ 的样品中可以观察到一些SAPO-11球形聚集体, 同时也 存在少量条状晶体. 结合XRD结果推测, 此条状晶体有 可能是XRD上衍射峰位于 $2 \theta=5.4^{\mathrm{o}}$ 和 $10.8^{\circ}$ 处的未知结晶 相. 随着晶化时间的延长, 无定形物质逐渐减少, 在 $1.83 \mathrm{~h}$ 时条状晶体消失, 而球形聚集体的量明显增加. 此后随 着晶化时间的延长, 固体样品的形貌基本保持不变.

\subsection{XRF结果}

我们采用XRF检测了不同晶化时间样品的元素组 成. 图4给出了固体样品中 $\mathrm{P}, \mathrm{Al}$ 和 $\mathrm{Si}$ 三种元素的相对摩尔 含量随晶化时间的变化. 可以看到, 在晶化初期 $(1.83 \mathrm{~h}$ 之 前), 固体样品中的P含量由 $0.75 \mathrm{~h}$ 的 $26.14 \%$ 增加到 $1.83 \mathrm{~h}$ 的 $47.89 \%$, 而 $\mathrm{Al}$ 含量由 $71.9 \%$ 降至 $50.05 \%$. 这表明随着晶 化的进行, 来自原料中的铝物种不断溶入液相, 同时也说 明晶化初期SEM中观察到的无定形物质主要是未反应 的铝物种. 随着晶化时间的进一步延长, 固体样品中的 $\mathrm{Al}$ 含量保持在 $50 \%$, 而 $\mathrm{P}$ 含量呈现微弱的下降趋势, Si含 量则相应增加, 硅和磷相对摩尔数之和恒定在 $50 \%$ 左 右, 与 $\mathrm{Al}$ 的摩尔数相当. 值得注意的是, $1.22 \mathrm{~h}$ 的样品中 $\mathrm{Si}$ 含量呈现一个局部的高点. 另外, 从晶化初期具有较高 结晶度的1.83 h 样品到最终的晶化产品, $\mathrm{Si}$ 的相对摩尔含 量变化幅度要明显大于磷铝两种元素: $1.83 \mathrm{~h}$ 样品中硅 含量为 $2.06 \%, 17.83 \mathrm{~h}$ 样品中为 $4.66 \%$, 增长了 1.26 倍.

\section{4. 晶化液的 $\mathbf{p H}$ 值}

晶化液的 $\mathrm{pH}$ 值与合成体系中各物料状态的变化密 切相关, 如图5所示. 在 $2.33 \mathrm{~h}$ 之前, 晶化液的 $\mathrm{pH}$ 值随晶化 时间的延长快速增加; 之后至晶化结束其变化较小. 结 合上文结果, 我们认为晶化初期至 $2.33 \mathrm{~h}$ 期间合成体系 $\mathrm{pH}$ 值的快速增加是由于磷酸与氧化铝反应而被消耗所 致(对应于分子篮的大量生成). 另外, 随着溶液中磷的减 少, 配料初期与磷酸等酸性物种结合的有机胺被逐步释 放也将导致体系 $\mathrm{pH}$ 值的升高. $2.33 \mathrm{~h}$ 之后, 晶化液的 $\mathrm{pH}$ 
值基本不发生变化.

\section{5. 固体MAS NMR结果}

不同晶化时间制得样品的 ${ }^{31} \mathrm{P}$ 和 ${ }^{27} \mathrm{Al}$ MAS NMR谱示 于图6. 可以看出, $0.75 \mathrm{~h}$ 样品的 ${ }^{31} \mathrm{P}$ 谱中只有一个中心位 于 $\delta=-16$ 的宽包峰, 可归属为无定形磷酸铝相中的磷物 种 $\mathrm{P}(\mathrm{OH})_{x}\left[\mathrm{OAl}(\mathrm{tet}]_{y}\left[\mathrm{OAl}_{(\mathrm{oct})}\right]_{4-(x+y)}(x=1,2)^{[18]}\right.$. 对应的 ${ }^{27} \mathrm{Al}$ 谱存在两个共振吸收峰, 分别归属为无定形铝源及无定 形磷酸铝中五配位 $(\delta=8)$ 和六配位 $(\delta=-12)$ 铝物 种 ${ }^{[11,19,20]}$. 晶化1.22 h后, ${ }^{31} \mathrm{P}$ 谱图上的宽包峰变得很弱, 而 在 $\delta=-24,-28.4$ 和 -33.6 处出现了一组相对尖锐的峰. 宽 包峰的基本消失说明样品中无定形磷酸铝的量已经很 少. 尖锐的组峰应对应于具有较高结晶性质的磷酸铝材 料中四配位磷物种 ${ }^{[12,18]}$, 显示此时固体样品中磷物种的 缩合度已经较高, 但同时也说明磷的配位环境比较复杂. ${ }^{27} \mathrm{Al}$ 谱图的变化也较大, 其在 $\delta=38.8$ 处出现了一个不太 对称的强共振峰, 同时 $\delta=8$ 处峰明显变弱. 一般而言, 由 微孔磷酸铝材料中四配位铝物种所引起的共振峰在 $\delta=$ $35 \sim 8$ 处 ${ }^{[21]}$. 因此1.22 h样品中 $\delta=38.8$ 的新峰可归属为 四配位铝物种. $\delta=8$ 处峰变弱则说明固体样品中无定形 铝源的含量降低, 与XRF结果一致. 值得注意的是, $\delta=-$ 12处六配位的铝峰并没有随无定形磷酸铝和铝源的溶 解而变弱, 推测有新物种贡献于此峰. 晶化 $1.83 \mathrm{~h}$ 及其后 几个样品的 ${ }^{31} \mathrm{P}$ 和 ${ }^{27} \mathrm{Al}$ MAS NMR谱基本不发生变化, 其 中 ${ }^{31} \mathrm{P}$ 谱中位于 $\delta=-32$ (包含 $\delta=-26$ 肩峰) 处的峰可归属 为 SAPO-11分子篮的骨架四配位磷物种 ${ }^{[12,20]},{ }^{27} \mathrm{Al}$ 谱中 $\delta$ $=37$ 和 8 处峰则分别归属为分子篮的骨架四配位和骨架 五配位铝物种 ${ }^{[12,17]}$, 说明此时SAPO-11晶化已经比较完 全, 与前面XRD, SEM和XRF结果一致.

对比晶化后期的NMR谱, $1.22 \mathrm{~h}$ 样品中 ${ }^{27} \mathrm{Al}$ 谱在 $\delta=$ -12 处的六配位峰应该与中间相的生成有关; $\delta=38.8$ 处 的不对称峰除固体样品中SAPO-11分子篮四配位铝物 种 $(\delta=37)$ 的贡献外, 还应该包含中间相中铝物种的贡 献; 相应地, ${ }^{31} \mathrm{P}$ 谱中多个谱峰的存在也与中间相有关. 这 说明中间相中磷铝物种的配位环境比较复杂.

图7(a)是不同晶化时间制得样品的 ${ }^{29} \mathrm{Si}$ MAS NMR 谱. 由图可见, 所有样品均呈现比较相似的宽化共振峰. 其中 $1.22 \mathrm{~h}$ 样品在约 $\delta=-109$ 处峰所占的比例要高于其 它样品. 参照文献[2,22 24], SAPO分子篮中硅以 $\mathrm{Si}(n \mathrm{Al}$, (4-n)Si) ( $n=0 \sim 4)$ 的形式存在于分子篎骨架上, 随着硅周 围相连的铝原子数的降低, 硅的共振峰逐渐向低 $\delta$ 值位 移 $(\delta=-90 \sim-110)$. 因此, 对 $1.83 \mathrm{~h}$ 及其后结晶比较完全 的固体样品, 其硅谱上宽化的共振峰说明样品骨架中有
多种硅配位环境共存. 但是对晶化前期 $1.22 \mathrm{~h}$ 样品, 由于 有两种晶相共存, 且样品中含有少量的无定形物质, 对硅 谱的归属比较困难. 为了进一步弄清楚各谱峰的归属, 采用 ${ }^{1} \mathrm{H} \rightarrow{ }^{29} \mathrm{Si}$ 交叉极化的方法测定样品的 ${ }^{29} \mathrm{Si}$ CP MAS NMR谱, 结果示于图7(b). 可以看到, $1.22 \mathrm{~h}$ 样品的谱峰在 交叉极化前后变化不大, 而其它样品则从原来的宽包峰 变为中心在 $\delta=-93.7$ 处比较尖锐的峰(对应于 $\mathrm{Si}(3 \mathrm{Al}$ )环 境). $1.22 \mathrm{~h}$ 样品与其它样品在交叉极化硅谱上 $\delta=-75 \sim$ -100 区间峰强度的差别应该与中间相的生成有关, 其在 $\delta=-110$ 处峰的归属则仍比较困难, 可能与中间相, 或未 完全溶解进入液相的原料有关. 对比分析晶化后期样品 在交叉极化前后的硅NMR谱, 我们认为此阶段样品中硅 原子主要以硅岛的形式存在于分子篮骨架中. 按照硅进 入 SAPO 分子篎骨架的 SM2 ( $\mathrm{Si}$ 替代P) 和 SM3 (Si 替代 P-Al对)机理,硅在骨架中可以形成5硅岛和8硅岛. 5硅岛 中对应 4 个 $\mathrm{Si}(3 \mathrm{Al}, 1 \mathrm{Si})$ 和 1 个 $\mathrm{Si}(4 \mathrm{Si})$ 环境, 而8硅岛中则对 应有 4 个 $\mathrm{Si}(3 \mathrm{Al}, 1 \mathrm{Si}), 2$ 个 $\mathrm{Si}(2 \mathrm{Al}, 2 \mathrm{Si})$ 和 2 个 $\mathrm{Si}(4 \mathrm{Si})$ 环 境 ${ }^{[25,26]}$. 可以看到, 不论是5硅岛或8硅岛都将导致样品 中较多 $\mathrm{Si}(3 \mathrm{Al})$ 环境的存在, 与本文 ${ }^{29} \mathrm{Si} N \mathrm{NMR}$ 结果一致.

\section{6. 晶化过程分析}

根据上面的表征结果, 对SAPO-11分子篮晶化过程 分析如下.

初始凝胶物料在升温过程中即开始发生剧烈的变 化. 晶化温度到 $100{ }^{\circ} \mathrm{C}$ 时, 多数的磷源和硅源溶解进入液 相, 而铝源则基本仍保持在固相, 以一水软铝石胶的形式 存在, 同时固体样品中也存在一定量的无定形磷酸铝; 晶化温度升至 $150{ }^{\circ} \mathrm{C}$ 时, 大量的铝源和无定形磷酸铝溶 解进入液相, 同时 SAPO-11晶体和一种未知晶相的结晶 物质开始生成, 固体样品中铝含量大幅下降, 磷和硅的含 量明显增加, 特别是硅含量呈现一个局部的高点. 此时 合成体系的 $\mathrm{pH}$ 值也从 $100{ }^{\circ} \mathrm{C}$ 时的 3.26 增至6.02. 理论上 在晶化初期, 随着体系 $\mathrm{pH}$ 值的升高, 无定形氧化硅更容 易溶解进入液相, 推测其在固体样品中的含量明显增加, 这应该与中间相的生成有关, 说明中间相还含有硅磷铝. 从NMR结果推测, 中间相中几种元素的配位环境相比于 SAPO-11要更复杂; 晶化温度升高到 $200{ }^{\circ} \mathrm{C}$ 时, 无定形氧 化铝和结晶相全部溶解, SAPO-11开始大量生成, 样品的 相对结晶度达到 $81 \%$. 相应地, 合成体系的 $\mathrm{pH}$ 值也升到 7.34. 此时样品中硅的摩尔含量仅为 $2.06 \%$, 其主要以硅 岛的形式存在于SAPO-11的骨架中; 进一步延长晶化时 间到 $17.83 \mathrm{~h}$, 固体样品中硅磷铝的配位环境保持不变, 铝 的相对摩尔含量保持在 $50 \%$ 左右, 磷含量轻微下降, 同时 
硅含量增加到 $4.66 \%$, 意味着在晶化后期, 硅进入分子篮 骨架的程度明显增加.

\section{7. 硅在SAPO分子篮晶体中的分布}

依据上面对晶化过程的分析, 我们推测硅在 SAPO-11分子篮晶体中的分布有可能是不均匀的, 即从 内向外呈现递增的趋势, 从而导致晶体外表面富硅. 为 了验证我们的推测, 对 $17.83 \mathrm{~h}$ 的样品进行了XPS分析, 结 果列于表1. 可以看到, 样品外表面的 $\mathrm{Si} / \mathrm{Al}$ 摩尔比高达 0.48 , 远高于体相的 0.09 , 和我们的分析完全吻合. 这种硅 逐渐进入SAPO-11分子篮骨架的现象应该与合成体系 的 $\mathrm{pH}$ 值变化密切相关. 由于氧化硅的等电点在 $\mathrm{pH}=2$ 附 近, 晶化初期合成体系是酸性的, 不利于氧化硅原料的解 聚, 限制了其参与分子篮骨架的形成反应. 随着晶化的 进行和结晶产物的生成, 合成体系的 $\mathrm{pH}$ 值逐渐升高, 氧 化硅原料的解聚程度增加, 液相中活性硅物种的量增加, 从而使其进入分子篮骨架的量明显增大, 并导致分子篮 晶体外表面富硅.

考虑到SAPO分子篮水热合成中普遍存在随着晶化 的进行, 合成体系 $\mathrm{pH}$ 值逐渐增加的现象, 我们推测多数 SAPO分子篎都应该存在表面富硅的情况(晶体中硅含 量从核到壳递增), 因而采用水热法合成了 SAPO-5, SAPO-34和SAPO-35分子篮, 并在相同的条件下进行了 XPS测试, 结果列于表1. 可以看到, 几个样品的表面硅含
量均高于体相的, 和上面的推测完全一致. 另外, 每种分 子篮表面富硅程度也有所差别, 这有可能与合成体系的 $\mathrm{pH}$ 值及分子篮自身的骨架结构有关. SAPO分子篮表面 富硅的现象也见诸报道过 ${ }^{[27,28]}$, 因此该现象应为 SAPO 类分子篎晶化中一个比较共性的特点.

\section{4. 结论}

采用多种表征手段研究了SAPO-11分子笕的水热 晶化过程. 结果表明, 在晶化初期, 硅磷铝原料和无定形 磷酸铝凝胶溶解进入液相, 同时生成SAPO-11和一种具 有硅磷铝组成的结晶物. 随着晶化的进行, 中间相溶解, SAPO-11大量生成, 呈现快速晶化的特征. 晶化进行 2.33 $\mathrm{h}$ 后, 分子篮的结晶度接近 $100 \%$, 其保持至晶化结束仅发 生微小变化. SAPO-11的晶化过程遵循液相晶化机理, 不 过在晶化初期晶核生成的初始阶段固相转变机理也可 能发生. 硅原子从晶化初期直接参与晶化进入SAPO-11 分子篮骨架, 并主要以硅岛形式存在. 依据分子篮中的 氧化硅含量随晶化时间延长而逐渐增加的现象, 并结合 XPS分析结果, 我们推测硅在SAPO-11分子篮晶体中的 分布不均匀, 具有从内向外其含量递增的特点. 另外, 我 们也发现其它SAPO分子笁也存在这一特点, 进而推测 水热合成体系中 SAPO分子篮晶体内硅分布不均匀应该 是一种比较共性的现象. 